\title{
CONTEMPORARY SOCIAL PROCESSES OF NAGYECSED, WITH SPECIAL REGARD TO THE SITUATION OF THE ROMA POPULATION
}

\author{
Authors: \\ Zsolt Soós (Ph.D.) \\ Debreceni Egyetem (Magyarország) \\ Gyula Szabó (Ph.D., Habil.) \\ Debreceni Egyetem (Magyarország) \\ E-mail address of the first author: \\ soos.zs@ped.unideb.hu
}

Lectors:

\author{
Gábor Biczó (Ph.D., Habil., Prof.) \\ Debreceni Egyetem (Magyarország) \\ Imre Pornói (Ph.D.) \\ Debreceni Egyetem (Magyarország)
}

Soós, Zsolt \& Szabó, Gyula (2020). Contemporary Social Processes of Nagyecsed, with Special Regard to the Situation of the Roma Population. Különleges Bánásmód, 7. (1). 45-57. DOI 10.18458/KB.2021.1.45

\begin{abstract}
Our research carried out in Nagyecsed is part of a longer series of research consisting of ten items, in which we primarily seek to map the main social characteristics and current social processes of settlements with lower population in the less-favoured regions of the country. In the course of the research, our goal is basically to get to know and present the perspectives of the local residents. A crucial consideration in the selection of the research sites was that smaller settlements in these peripheral regions are experiencing rather unfavourable socio-demographic trends, including in particular the declining population, aging and the growing proportion of disadvantaged populations, including disadvantaged Roma. These processes - if no significant changes take place - project an even more unfavourable vision than at present. The unfavourable socio-demographic tendencies can be clearly seen in Nagyecsed. In connection with this, the main goal of the research is to explore the situation of the Roma, as well as the local community relations, especially the coexistence characteristics of the Roma and non-Roma population.
\end{abstract}

Keywords: Roma communities, non-Roma population, living conditions, coexistence

Disciplines: Sociology

\section{Absztrakt}

NAGYECSED KORTÁRS TÁRSADALMI FOLYAMATAI, KÜLÖNÖS TEKINETTEL A ROMÁK HELYZETÉRE

A Nagyecseden lefolytatott kutatásunk egy hosszabb, tíz elemből áló kutatássorozat része, amelyben elsősorban az ország kedvezőtlenebb helyzetű régióiban fekvő, kisebb lakosságszámú települések főbb társadalmi jellemzőinek, aktuális társadalmi folyamatainak a feltérképezésére törekszünk. A kutatás során 
alapvetően a helyi lakosok nézőpontjainak a megismerése és megjelenítése a célunk. A kutatási helyszínek megválasztásában döntô szempont volt, hogy e perifériális régiók kisebb településein meglehetősen kedvezőtlen szocio-demográfiai folyamatok zajlanak, ideértve különösen a települési lakosságszám csökkenését, az idôsödést és a hátrányos helyzetű lakosság, köztük a hátrányos helyzetû romák számarányának a növekedését. $E$ folyamatok - amennyiben nem történnek jelentősebb változások - még a jelenleginél is kedvezőtlenebb jövőképet vetítenek előre. E kedvezőtlen szocio-demográfiai tendenciák egyértelműen tetten érhetőek Nagyecseden. Ehhez kapcsolódóan a kutatás kiemelt célja a romák helyzetének, továbbá a helyi közösségi kapcsolatoknak, ezen belül elsősorban a romák és a nem romák együttélési jellemzőinek a feltárása.

Kulcsszavak: roma közösségek, nem romák, életkörülmények, együttélés

Diszciplina: szociológia

\section{Research methods and tools}

Several methods were used in the research, on the one hand we prepared the analytical summary of the social statistical data on the settlement (e.g. population change, etc.) and on the other hand we reviewed the most important documents about the region and the settlement. The main method of the research - in line with its approach, i.e. in order to present the point of view of the locals - we chose the oral interview, including the partially structured individual interview (Falus, n.d.). Using preliminary mapping and then the snowball method (Babbie, 1996), we recorded 22 individual interviews and conducted focus group interviews with students in the graduating class of the local grammar school. We intended to make the respondents sociodemographically diverse, and thus to channel opinions from as many groups of the settlement as possible. Consequently, the respondents included young people, the elderly, family people, single people, people belonging to the Roma and nonRoma ethnic groups, and in terms of occupation we interviewed teachers, public education and social professionals, an economist, a community organizer, a wood carving artist, a self-employed skilled worker, a tradesman, an unskilled worker in public works, a disability pension beneficiary, a pensioner, unemployed people, etc.

\section{Nagyecsed}

The small town with a population of 6467 (KSH, 2019) is located near the Romanian border, at the confluence of the Szatmár plain and the Nyírség region. The Trianon treaty fundamentally affected the situation of the settlement. Before 1920, Nagyecsed belonged to the catchment area of the bustling city of the region, Szatmárnémeti (Satu Mare). Today this city has about 102,000 inhabitants, but already back in 1920 had 38,000 residents (RPL, 2011), and on the one hand, it provided a market for the agricultural products of the population living here, and on the other hand provided all kind of city centre functions (from cultural and educational opportunities to higher quality employment chances) for the inhabitants of Nagyecsed. (Dankó, 1994) This role could only be partially taken over by Mátészalka (KSH, 2019) with a population of 17,036 , today's district centre. As a result of this border change, Nagyecsed became an inaccessible, peripheral settlement in one of the most disadvantaged areas of the 
country, due to the ceased transit traffic it turned into - as the locals put it - "a real sack town".

Due to this isolated situation, and perhaps partly due to the peculiarities of historical development, the municipality tries to organize and provide as many public services as possible for the population on the spot. The city also has a public primary school, a parochial primary school and grammar school, a kindergarten with three member institutions, a day-nursery, a unified social institution, a house of culture, a community house, a Roma community house, and a "civil house" maintained with the help of the municipality.

The same applies to the demographic processes of Nagyecsed, what can be observed in the vast majority of peripheral small settlements in Hungary (Bálint and Obádovics, 2018; Gödri, 2018), and even in other developed countries of Europe (EBRD, 2019), i.e. the outmigration of young people and partly middle-aged people is typical. The population has been declining almost continuously since 1960, when 8348 people lived in Nagyecsed. At the same time, the number and proportion of the Roma population in the city is constantly growing, at the time of the 2001 census, only $7.4 \%$ of the 6,797 local residents declared themselves to belong to the Roma minority. ( $\mathrm{KSH}$, 2002). However, there is a significant difference between the numbers based on self-classification and external classification (i.e. the Roma are those, who are considered to be Roma by Roma and nonRoma). Based on the external classification, a smaller proportion of people classified as Roma declare themselves to be Roma. "Ahmed et al. (2007) estimate this ratio at 38\% in their study, while Ladányi and Szelényi (2004) estimate it at 33\%." (In: Pénzes, Tátrai, Pásztor, 2018:6) Based on the above, the proportion of Roma may have ranged between $19.5 \%$ and $22.5 \%$ in 2001 . At the time of our research, in 2019, both the local government and the locals we interviewed estimated the proportion of Roma to be over 30\%.
It is also important to highlight that the vast majority of local Roma, especially Romungró Roma people, are disadvantaged or multiple disadvantaged. Consequently, in addition to aging, the deterioration of the general social situation is also characteristic of Nagyecsed.

\section{The history of Nagyecsed in headlines}

In addition to the geographical features of the settlement, the historical traditions, customs and attitudes spanning generations also determine the way of thinking of today's inhabitants to a certain extent. In the past in the Ecsedi marshes fishing and a special form of it, called "pákászat" had a significant role, but these activities have disappeared by now. (Szabó, 2019) This wetland environment, on the other hand, has resulted that the arable land, as well as land-based animal husbandry, especially horse breeding had enormous value. All this led to the development of a significant agricultural and equestrian cult (Szállási, 2008), which strengthened again in the settlement after the democratic transformation. In connection with the agricultural cult, village traditions such as folk dance, folk music, and even the association that kept the "bog outlaw cult" alive in Nagyecsed have been re-strengthened, too. In addition, gypsy music and gypsy dance also have a significant tradition that has been preserved in the settlement through generation. An important element of the local identity is that the folk dance of the Hungarian and Oláh Gypsy communities became part of the world heritage at the same time. (The common language refers to the group as "Oláh" gypsies, which is a Hungarian version of the Vlach.) However, no such cultural heritage remained in the Romungro community.

The other significant factor that affects somewhat even the mindset of the current population is that Nagyecsed was once a type of market town that held significant privileges. The 
favourable location, the attachment to the Transylvanian Principality and the privileges attracted the settlers, and these favourable conditions - coupled with the diligence of the locals - resulted in continuous development until the fall of the Rákóczi War of Independence (1711), as well as strong self-awareness. (Dankó, 1994) After that, however, all the previous privileges of the settlement "accused " because of its role in the War of Independence were revoked, and the landlords following Rákóczi treated the locals as serfs. However the "Ecsedians" with strong self-awareness did not accept this step back, especially the curtailment of their freedom, and on 19 January 1776, they filed a lawsuit against Count Antal Károlyi at the Szatmár County Court against the abolition of their privileges and against their demotion into serfs. However, the verdict confirmed the demotion of the people of Nagyecsed and their obligations to the landlord, so they appealed against it. With this, the infamous „100-year-long copyholder lawsuit” continued, which ended only in the 19th century, during which the pride and self-awareness of the locals was not broken even by the fact that they were impoverished in this lawsuit. (Éble, 1912) Selfesteem was even more important than making a living. This form of strong self-esteem and attitude also characterized our interviewees. As one of our interviewees (36-year-old woman, public education professional) put it: „, They are characterized by a special locale folklore, a kind of attitude and pride. They had many privileges as long as there was a castle in Ecsed, they did not pay tax, hence the pridefulness".

However, the tribulations of the inhabitants of Nagyecsed did not end with the lawsuit, as had been discussed earlier, the peace treaty of Trianon adversely affected the settlement related to Nagybánya. The population strongly attached to the land could not enjoy the beneficial effects of the land distribution after the Second World War for a long time, collectivization - according to our interviewees - was acknowledged by many locals brokenly. (Nevertheless there are those who think positively about the last decades of the socialist era, in part because local and surrounding land holdings are now concentrated in the hands of a few people, while in the 70 s and 80 s the land - handled by the cooperative - provided subsistence for a significant proportion of locals.)

This historical legacy is still somewhat perceptible in the settlement today, pride and selfesteem, as well as distrust of strangers - and consequently some distrust of local ethnic groups characterize a significant part of the people living here.

\section{Coexistence of ethnic sub-communities in Nagyecsed}

Henriett Szabó (2019) published a study on the coexistence of local Roma and non-Roma communities today, basically with an ethnographic approach. The information in that study on the traditions, socio-demographic and socio-cultural characteristics of the locals, their system of values and norms, and their relationship to each other was basically confirmed by our research.

„The local society of Nagyecsed consists of three ethnic sub-communities - Hungarian, Romungró and Oláh Gypsy. The relations between the subcommunities determine the internal relations and operational characteristics of the local society." (Szabó, 2019:165) The residences of the local ethnic sub-communities have been completely separated in the past and to a significant extent they are even today, which is a fact that in itself has a significance in terms of local conditions. The non-Roma population lived in and near the city centre, while the Romungrós and the Oláh Gypsies used to live in segregates at two opposite ends of the settlement (as the locals say, „From Kraszna here and beyond." or „On the bridge from here and beyond the bridge."). In this respect, the situation of the 
Romungrós has not changed to this day, they live in the segregates of the part of the city close to Mátészalka, practically without exception. Their living conditions, in line with their sociodemographic characteristics, are still very unfavourable today. A significant part of the population living here has at most a primary education, or even a lower level of education, and consequently a significant proportion of them are unemployed or living on low-paid public works (Szabó, 2019). Most of the houses are in poor condition, sometimes with very low comfort level, and for many families living here, various utilities (mostly the electricity) have also been switched off due to the accumulated debts. Many families carry water from the public well to everyday life, and many also use the laundry service in the community house. (,The washing machine spins all day." 42-year-old man, head of institution) It follows from this situation - based on Maslow's theory of needs hierarchy (1970), i.e. as long as our basic needs (food, adequate shelter, security) are not met on a lasting and acceptable basis, the need to meet higher level needs (e.g., the need for beauty, aesthetics) cannot appear - so the courtyards are also neglected. Marital cohabitation is not typical in this community today either, but early cohabitation and childbearing (typically from the age of 15-16) and a larger number of children are still common today. The proportion of large families in Szabó's study sample (2019: 178) is as follows: "More than $60 \%$ have three or more children. This proportion is barely $18 \%$ for Hungarians and $11 \%$ for Oláh Gypsies."

In contrast, the situation of a significant part of the Oláh Gypsy community has changed to the present day. An increasing group of the Oláh Gipsy population is getting more educated, with a significant proportion of them having professional training or high school diploma, in some cases even a degree. Some of these Oláh Gypsies, who partly through some of these qualifications - have an adequate level of regular income, nowadays they live in or around the city centre, in conditions that can be said to be average or even better than average at the local level. In other words, some non-Roma and Oláh Gypsies now live in the same neighbourhood, and the members of these two ethnic sub-communities are more open to each other than to the disadvantaged and multiple disadvantaged Romungrós. In Szabó's words (2019: 180): , [...] it is the more accepting and open attitude towards each other's community between Hungarians and Oláh Gypsies, which determines the development of relations." Proximity itself, and thus getting to know each other, strengthens this process of mutual acceptance, as prejudices are largely based on negative generalizations resulting from a lack of knowledge. (Forgas, 2007).

At the same time, the greater mutual acceptance of Oláh Gypsy and non-Roma local communities, which is confirmed by the existence of this type of mixed marriage (although their number is not significant today), is not a new phenomenon. As one of our 59-year-old Oláh Gypsy women interviewee, who works as a public worker, put it: "The old people told us that girls, you have no place beyond the Kraszna, but you have places everywhere on this side of the Kraszna River." In other words, they can marry other Oláh Gypsy or even non-Roma boys, but there is "no place" for Romungrós on the other side of the Kraszna River.

In addition to the unfavourable wealth and income status of the local Romungró people, the significantly different socio-cultural traditions of the two ethnic sub-communities, and thus their different attitudes and lifestyles play a significant role in this mutual separation and rejection. The Oláh Gypsy families, like the non-Roma community, lived and live under stricter rules and norms, while the Romungrós „[...] live more freely, more casually." (42-year-old Romungró woman, head of institution) Several of our 
interviewees pointed out that the love of children is especially characteristic of both Roma ethnic communities, as our kindergarten teacher interviewee (a 30-year-old Oláh Gypsy woman) put it: „Roma parents are very attached to their young children, it is much more difficult for them to leave their children here in the kindergarten than Hungarians [...] Sometimes they cry outside on the street."

At the same time, there is a big difference in terms of conscious upbringing, value transmission, and thus preparation for school, and for a future "more successful life", and even in terms of conscious childbearing. However, the limited nature of conscious education and the transmission of values is not only a matter of "tradition". Many in the literature on social work and social pedagogy have pointed out that cumulatively disadvantaged, low-educated, often very young parents do not have the necessary knowledge and skills themselves, and due to their current situation and lack of their own experiential knowledge, they consider those social values (e.g. school-based knowledge) less important, that could help to create a more successful life. (Major-MészárosTatárné Kapus, 2011; Soós, 2018; Thirsch in Sárkány, 2011) As the documentary by Biczó and Szabó (2020) points out, in the local public primary school, which is mainly attended by children from cumulatively disadvantaged Roma families, the first, priority task of educators is to facilitate the acquisition of those skills that are not mastered at home, but essential for school progress and future success (e.g. basic standards of conduct, rules, including learning acceptable ways of conflict management, etc.).

In this respect, as Rákó's (2017) research points out, the role of public educational institutions is (also) outstanding nowadays. In the Oláh Gypsy families, the conscious transmission of the stricter and more detailed system of rules was especially important in the past, and the families and the community as a whole have placed significant emphasis on it, and continue to do so today. This is well exemplified by the previous activity of our 59year-old, Oláh Gypsy woman interviewee, who, as a granddaughter of the former local voivode considered and still considers the religious and moral education of Roma children important. „At home, the kids gathered with me in the evenings. There were many of them, back and forth even on the ground. [...]They loved to go there, and not only because they always got some fatty bread with onions, I always did it so that the kids wouldn't go home bungry. [...] As much as they asked for, they got to eat and drink, just to make them learn [...] We studied the Bible, we learned the morality, just to learn what is right."

From the interviews we conducted, as well as from the research of Szabó (2019), it can be seen that a kind of partial acculturation process has taken place in the last decades among the Oláh Roma population in Nagyecsed. In doing so, they abandoned or relegated certain traditions (e.g., early cohabitation and childbearing), values (e.g., language use), and instead, they adopted, at least in part, the customs, attitudes, and language of the majority.

However language use in the families has not completely disappeared, but has become more context-related. As an example, it can be observed in several families that the grandparents talk to their grandchildren in Romani, who already answer in Hungarian. All this contributed to the further strengthening of the local integration of the Oláh Roma community. Szabó (2019: 187) evaluates this process as follows: „In Nagyecsed, the Oláh Gypsy community treats the acculturation process with a reflexive awareness, which can be defined as an event that promotes adaptation to the majority. According to this, the abandonment of certain customs, the desertion of certain elements of material culture, the changes in the order of values are part of the acculturation process, which is not a loss for them, but a condition for the social integration of the Oláh Gipsy community." 
In this respect, as a result of the recent period, our interviewees highlighted the more conscious childbearing planned for the mother's twenties, i.e. after graduating from school, the priority given to children's schooling and the more conscious allocation of money.

„It is a traditional rule, to have a maximum of two cbildren. It's a shame if you can't support your child [...] Earlier it was typical among the Oláh gypsies that the girl was eloped when she was in the 7th-8th grade, I also had my first suitor at the age of $13[\ldots]$ But they realized that it must be done later, they had to have a job, they had to work so they could keep the kids properly [...] nowadays, many of them get a profession, a bigh school diploma, and even a degree." (30-year-old Oláh Gypsy woman, kindergarten teacher)

"Today, it is the minimum, the basic requirement to have 8 classes for girls as well. But not only that, but to have some kind of profession, to work [...] It wasn't like that with us yet, the women weren't so independent, but it's good that they achieved that. We were completely dependent on our busband."(61-year-old Oláh Gypsy woman, housewife)"

„The Roma had to learn to allocate money, and it is going better than before. In the old days, when you went in to a Hungarian, you asked for 100 forints, he took it out of the closet. You couldn't do that to a Roma. Today they know better, at least the Oláh Gypsies have learned that they have to economize on money." (59-year-old Oláh Gypsy woman, public worker)

Based on the lessons learned from the interviews, in addition to a greater degree of mutual acceptance between the Oláh Roma and non-Roma communities, the relationship between the Romungrós and the other two ethnic subcommunities has improved somewhat and social distances have decreased, although these distances are still rather big. This process was primarily aided by conscious local decisions and developments. At the same time, the change in the primary school system, with two primary schools, one (ecclesiastical) ,elite school" in the wording of the locals and one (state), ghetto school" operating in the settlement, hinders the reduction of social distances.

\section{Local interventions to support the situation} of the local Roma and the and coexistence of

\section{Roma and non-Roma people}

The management of the settlement has taken a number of targeted measures to improve the situation of the local Roma and the Roma - nonRoma coexistence. In addition, the local leaders and the mayor in particular, his personality, his attitude towards others - especially the fact that he treats all people equally and helpfully, regardless of ethnicity and social status - was mentioned by several as a factor that has had and continues to have a positive impact on all locals.

"The mayor also gives educated Roma an opportunity [...] the work of Gypsies is recognized in the same way as of the Hungarians. [...] The mayor also considers public workers to be buman, treats them bumanely, and this has a good effect on the Roma as well." (59-year-old Oláh Gypsy woman, public worker)

„Here, public workers are seen as bumans the same way." (24-year-old non-Gypsy woman, public worker)

Among the specific measures with a positive impact, a significant number of interviewees highlighted the following:

1. Employment of the Roma in the intellectual jobs of public institutions, in full-time or as public workers.

2. Targeted use of the development resources provided by the European Union, by establishing and maintaining institutions that 
improve the situation of the Roma and the relations between the Roma and non-Roma.

3. The (life-centred) educational and pedagogical activities of the teachers of public educational institutions, adapted to the students, their family circumstances and their disadvantages brought from the family.

1. Several of our interviewees highlighted that the local mayor considered and still considers it important that the local Roma should also be given opportunities in "intellectual" jobs. This type of employment has sometimes been forced by unfavourable local conditions:

"I've tried sewing, but it's not for me because I love the
hustle and bustle [...] I worked as a cleaner, I didn't like
it, and I experienced atrocities [...] I worked in the
cannery, but I didn't like that either [...] After the birth
of my second child, I wanted to go back to work, but by
then I realized that I wanted to be engaged with dance, to
work in a helping profession. I contacted the mayor who
placed me in the family care centre, back then still without
a qualification, so that I had to complete my training in
social care and nursing. [...] After learning social work, I
got an office in the local community centre, but I was there
alone, which I didn't like. I asked the mayor to bire
someone else to work with me [...] he bired an educated,
high-school graduate woman, and then the Roma came to
us many times to ask. for help [...] Later, when I had my
qualifications, I wanted to run a Roma community centre
[...] back. then it was not easy to accept a Roma being in
charge. But the mayor also took on this conflict, he was
fighting for me like a wolf [...] Its his main goal and he
does a lot to get as many Roma people into public
institutions as possible, [...] as many Gypsy employees as
possible, the greater part they work in public works, but
those who bave a degree are employed full-time. This is an
important goal for me too, I have managed to achieve a lot
in this." (42-year-old Romungró woman, head of
institution)

Well, there were a lot of problems at school, especially with children from the Western Segregate [...] they were also dirty, unkempt. I thought the solution for this would be to belp wash the children before school and keep a change of clothes at the school. After all, it is in vain to tell the family to change if they cannot do it because they do not have the opportunity, there is no water, and there is a lack of electricity. [...] And this was embraced by the mayor, which is why a community centre was built in the segregation, where it is possible to wash the clothes and bathe. [...] Nevertheless there were a lot of problems and conflicts left in the school. Thus came the idea that Roma women could help in school, an idea that was also supported by the mayor. This is how Roma women got into public institutions. That was about seven years ago. I was admitted to upper secondary school as a mentor, but at first it was very difficult for teachers to accept me, as there were those whose graduate daughters were unemployed. I also heard her saying "My daughter is unemployed with a degree, Timi with a primary school certification is working with the children $\leqslant$. True, only in public works [...] At first, the teachers didn't want me to go into the classroom, I could only talk to the children during the breaks. Once, however, I was allowed to go into the worst class and from just sitting there, the Oláh Gypsy children were ashamed of themselves and did not behave badly. Then they started to trust me, and when there was a shortage of teachers, they dared to send me to class alone." (43-year-old Oláh Gypsy woman, social pedagogue)

This type of employment has proved effective in several respects, has had a positive effect on the educational and employment advancement of those employed, has had a positive effect on Roma children and young people and also acted as a model for them. Many of them continued their education in secondary school as a result of this, and the joint work also helped to reduce prejudice between Roma and non-Roma. 
„Public works, the fact that this is also done here in public institutions, the positive result of this is that the Roma and non-Roma work in the same place and they get to know each other [...] a lot of stereotypes have become obsolete. [...] Working together helped a lot, there are also Roma ladies in the school, if they weren't here, we couldn't have known them. I had the chance to meet a lot of great Roma people”. (47-year-old non-Roma man, teacher)

2. As can be seen in the first part of the study, there are a number of public institutions in the small town, the establishment and maintenance of which is not a mandatory task of local governments, however they are aimed at meeting local needs and demands by channeling available financial resources, mainly from the European Union. One such institution is the above mentioned Community centre in the segregate, which has been set up and is being operated as part of a complex field program to eradicate segregation. In addition to the washing and bathing opportunities the institution also had a school support program (tanoda), which is planned to be restarted. Besides, there are a number of developmental sessions for Roma children, as well as a mentoring program and a program to strengthen the relationship between school, children and parents. In addition, they are in close contact with 48 families and provide them help by the tools of social work. And when we were there, they had just built greenhouses for growing vegetables.

There is also a community centre in this part of the village, for Roma people specifically, led by an interviewee of Roma origin (a 42-year-old Roma woman). In this centre the local Roma are provided with training opportunities or with assistance in managing their affairs.

In addition to the community centre, there is a smaller community institution that has an outdoor training ground. On average, the institution holds smaller cultural sessions twice a month, as well as almost continuously - competence development and vocational courses.

There is also a "civil house" there, aiming to preserve local traditions, which was created partly by the cooperation and work of the locals. This institution provides space for the programs of various associations, and even for local private events for a price significantly lower than the market price - for HUF 10,000 / day in 2019 (e.g. wedding, graduation, birthday celebration, etc.).

The common feature of these institutions is that they provide services and programs for the locals based on real and significant needs and requirements, and in the case of larger cultural events these programs are available for a much wider audience. At the same time, based on the narration of our interviewees and the research of Szabó (2019: 199), their other common feature is the transmission of a value system that focuses on mutual acceptance and the strengthening of a sense of belonging across different ethnic subcommunities. In this regard Henriett Szabó (2019: 179) stated the following: "In the interviews conducted during the research, almost all of the community leaders interviewed made references to the demonstrative nature of the activity. Demonstrating and undertaking the work of their groups to the local society was emphasized as an overall essential element of their activities. Several of them used the term »stand out« when describing what it means to demonstrate a system of values and norms represented in their work at programs, lectures. On the one hand, the "stand out« is a public opportunity to experience the sense of belonging of their own small community. In the dance ensemble the production of Oláh and Romungró performers, the distribution of food packages by Hungarian and Romungró association members or the joint cooking event of Oláh Gypsies and Hungarians are all forms of activities that function as a regular practice of crossing 
ethnic boundaries. It follows that the »stand out« demonstrating the work of local cultural organizations in Nagyecsed conveys to the whole society of the settlement the emerging transethnic ethos, which at the same time encourages to exceed the historically formed inter-group opposition." In other words, the established institutional system, and the active community life realized by it significantly contributes to the reduction of social distances between different ethnic subcommunities and to the strengthening of mutual acceptance. However Szabó (2019) also notes that this effect is (currently?) still strong only within the communities connected to these institutions.

Finally, it is to be noted that this diversified institutional system provides employment for many locals and public works opportunities for even more people.

3. Both domestic and international experiences show (MMSZ, 2020) that desegregation and catchup programs aimed at improving the living conditions of disadvantaged groups, including disadvantaged Roma, can only be truly effective if the various actors in the public sector, health care workers, social professionals and educators also work together. A further condition of effectiveness is that during the interventions - in accordance with the principles of life-cantered social pedagogical counselling (Thirsch in Sárkány, 2011) - the professionals also help the members of these families to acquire the knowledge and skills necessary for successful school and work advancement and the organization of successful family life, which are usually mastered during family socialization, transferring them from generation to generation. In other words, these professionals do not "only" implement professional-type interventions, but are "present" in the lives of the clients, and also try to take part in dealing with the problems arising from the shortcomings of previous family socialization.
Based on the experience and information gained locally and partly described earlier, significant changes have taken place in this regard in local public educational institutions. The first and predominant task of teachers, even before the start of their education activities is to transfer the knowledge and skills necessary for a successful school progress of the pupils and a more successful life in the future. (MMM, 2020)

\section{Characteristics and effects of public employment}

The significant local public employment can be included among the measures to improve the situation of disadvantaged local groups, including a significant proportion of local Roma, and besides, as mentioned earlier, the conditions of Roma non-Roma coexistence.

At the same time, the assessment of this rather extensive level of public employment, in which 413 people were employed in 2019 (for comparison: In Hajdúböszörmény, which has a population five times larger than Nagyecsed, and where also Romungros and an acculturated Oláh community, about 3,000 Roma people live together in a segregated environment, the number of public employees in 2019 barely exceeded 300). (data release of the local governments, 2019), is controversial at the local level, and from a scientific and analytical point of view as well (e.g. Pirisi, 2018). Of the fundamentally social-based public employment programs already in place between the two world wars, those were beneficial for the participants, in which they were able to do useful, productive work that served their self-esteem and often made them possible to enter the world of market work. (For example, the creation of needless "hills of dearth" was not included in this circle). (Ferge, 1986) In addition to providing a minimum level of livelihood, public employment still aim to strengthen the ability of those involved 
to work, to strengthen their self-esteem and, ultimately, to serve only as a temporary, kind of emergency solution that is available for everyone and in the longer term it should guide the participants into the world of labour market. The practice applied in Nagyecsed partially meets these requirements. On the one hand, there are really meaningful and productive jobs, in addition to the jobs in the public institutions presented earlier, these include local crop production, the products of which are mainly used in local public catering, as well as paving stone production. At the same time, due to the disproportionately large number of public employees, in some smaller public institutions, for example at the community centre or the civil house, 10-15 public employees carry out the work of one or two people in cleaning or gardening. At this local level, the "in-door" unemployment of the former socialist societies (Andorka, 2006) is practically realized - at least in part - in a much more extreme form. However, this way of employment, in which there is quite a little of work for the employees, and where the rules of employment, e.g. the rules of attendance are very flexible, in the vast majority, except in a few cases, does not prepare and thus does not lead the participants to the labour market. „Thus, this type of public work does not integrate them back into the labour market. Here they are permanently trapped in this situation." (42-year-old man non-Roma man, social worker)

The question rightly arises whether at least a part of the disadvantaged or cumulatively disadvantaged population, who often suffer from low selfconfidence and are more afraid of the new circumstances than average, are deterred by the public works from the labour market employment and thus from reaching a much more favourable income situation and more favourable living conditions. As one of the social workers interviewed put it: "It is questionable whether the community centre in the segregate is not a form of „segregation” itself, because the Roma do not even go to the town centre, they ask for help in managing their affairs here, local children come here for the programmes, they apply here for public works, if they can." (42-year-old man nonRoma man, social worker)

At the same time, the majority of public workers surveyed - while emphasizing that the salary is very low - still consider this option favourable, moreover, many of them see it as the only realistic way of employment in addition to raising children. This may be due, at least in part, to the fact that in a significant proportion of Roma families, even in the case of the parents of the respondents, women had the sole responsibility of raising children and doing housework, and doing so is still considered difficult to reconcile with "working in a full (labour market) position".

„Here, for a family woman, only public works can come into play, because children have to be taken to kindergarten, if they are sick, she has to stay at home with them, and these are not problems in public works, they are allowed to do so. That's a good thing in public works." (26-year-old Romungró woman)

"Then I worked in a shop here in Ecsed, but I had to work every day outside of Sunday, even if the child was sick, they didn't let me go and they only paid 70,000 [...] So after the second child, after GYES (child care benefit), I became a public worker. Parents with a small child, if they don't have help, can't manage to go to a factory to work. [...] All is left for me was public works." (24-year-old Oláh Gipsy woman)

\section{Factors hindering the strengthening of social integration}

In addition to the spatial segregation of the different ethnic sub-communities, especially the Romungrós, a significant part of the locals surveyed consider that the biggest obstacle to local integration is the fact that the formerly unified 
primary school system has now been divided into two parts, „elite” and "ghetto" schools - and this view is supported by the relevant research results and the corresponding legal provisions prohibiting educational segregation (Act CXXV of 2003). The previously mentioned pedagogical work can only partially compensate for the fact that pupils with better and worse social background (in the latter case mostly of Roma origin), are no longer socialized in a common institution, so there is little chance to know and accept each other and also to learn from each other. As a result of segregation, children, who come from less affluent family backgrounds and are usually less motivated to attend school according to local teachers (as their parents often think of school as an unpleasant memory, and thus they have somewhat negative, sometimes dismissive feelings) so they are less likely to see a positive attitude towards school learning. It is important to emphasize, however, that the segregation of students is not based on ethnicity in the local church school, where children can be admitted after successful enrolment and in the case of following certain ecclesiastical rules. Students of Roma origin also attend the school, for example, five out of 12 people in the secondary school class interviewed in the focus group interview were of Roma origin. At the same time, the admission system and the prescription of certain religious rules - which is somewhat selfevident in the case of a church institution - still result that non-Roma and Oláh Gypsy children with a more favourable background are attending the church school in a higher proportion, which families are also more likely to follow church rules than Romungró families. Meanwhile, the vast majority of public school pupils, according to data provided by the headmaster of the institution, $90 \%$ of their 243 students are raised in multiple disadvantaged, predominantly Romungró families. In other words, as a result of these processes, at least in part, a kind of ethnic segregation develops, which obviously hinders the improvement of relations between ethnic sub-communities, especially between the Romungrós and the other two groups, and the strengthening of mutual acceptance.

"When I was a child, there was only one school, we went there, everyone could get to know everyone, everyone could make friends with everyone [...] It was only later that the Calvinist school was established, where there is admission. This became the elite school. The public school to which Roma go in the majority is the ghetto school. In the old days, the kids went over to talk and play more together, but now it's largely over [...] Nowadays people rather only keep in touch with friends and relatives" (36-yearold non-Roma woman, public education professional)

„There is a need for the relationship building program in which the task is to strengthen the relationship between parents, school, teacher and the kids [...] It is important as because of the two schools, the pull factor has been eliminated in the public school by transferring those with better skills to the other school." (42-year-old man non-Roma man, social worker)

The research work necessary for the preparation of the study was carried out with the support of the EFOP-3.4.3-16-2016-00021 project "A Debreceni Egyetem fejlesztése a felsőfokú oktatás minőségének és hozzáférhetőségének együttes javítása érdekében".

\section{References}

Andorka, R. (1996). Szociológiai. Budapest: Osiris.

Bálint, L. \& Obádovics, C. (2018). Belföldi vándorlás. In. Monostori J., Öri P., Spéder Zs.lt (szerk.): Demográfiai portré 2018. Jelentés a magyar népesség helyzetéröl. Budapest: KSH Népességtudományi Kutatóintézet. 217-236.

Babbie, E. (1996). A társadalomtudományi kutatás gyakorlata. Budapest: Balassi Kiadó. 
Dankó, I.(1994). Nagyecsed. Központi szerepkeör és önkormányzat a történelem sodrában. Debrecen: Ethnica

Éble, Gábor (1912). Az ecsedi 100 éves úrbéri per története. (1776-1877) Budapest: Franklin Társulat Nyomdája

Falus, I. (szerk.) (é.n.). Bevezetés a pedagógiai kutatás módszereibe. Budapest: Műszaki Könyvkiadó Kft,

Ferge, Zs. (1986). Fejezetek a magyar szegénypolitika történetéból. Budapest: Magvető.

Forgas, J. P. (2007). A társas érintkezés pszichológiája. Budapest: Kairos.

Gödri, I. (2018). Nemzetközi vándorlás. In. Monostori, J., Öri, P. \& Spéder, Zs. (szerk.): Demográfiai portré 2018. Jelentés a magyar népesség helyzetéröl. (pp. 237-270.) Budapest: KSH Népességtudományi Kutatóintézet.

Major, Zs. B., Mészáros, K. \& Tatárné Kapus, Cs. (2011). Az eltéphetetlen gyökér. Szeged: ÍRTÓ Bt PMJVÖ Családsegítő és Gyermekjóléti Szolgálata.

Maslow, A. T. (1970). Personality and motivation. New Yourk: Harper and Row (2nd ed.)

Pénzes J., Tátrai P. \& Pásztor, I. Z. (2018). A roma népesség területi megoszlásának változása Magyarországon az elmúlt évtizedekben. Budapest: Központi Statisztikai Hivatal: Területi Statisztikea, 58 (1): 3-26.

Pirisi, K. (2018). A közmunka szerepe a foglalkoztatáspolitikában, a szegénység és a bajléktalanság kezelésében. Doktori (Ph.D.) értekezés. (Gazdálkodás és Szervezéstudományok Doktori Iskola) Gödöllő: Szent István Egyetem

Rákó, E. (2017). A gyermekjólét-gyermekvédelem és a gyermekszegénység aktuális kérdései. In Rákó, E., Soós, Zs. (szerk.): Kibivásoke és válaszok. Tanulmányok a szociálpedagógia teriiletéról. (pp. 136147.) Debrecen: Debreceni Egyetemi Kiadó.

Rogers, C. R. (2019).Valakivé válni - A személyiség születése. Budapest: EDGE $2000 \mathrm{Kft}$.
Sárkány, P. (2011). Szociálpedagógiai elméletek. Paidea könyvek. Budapest: Jel kiadó.

Somlai, P. (1997). Szocializáció. Budapest: Corvina.

Soós, Zs. (2018). Szociális esetmunka. Debrecen: Debreceni Egyetemi Kiadó

Szabó, H. (2019). A lokális hagyomány funkciói a nagyecsedi kortárs közösségfolyamatokban. In. Néprajzi Látóhatár, XXVIII. évf. 2019. 1-2 szám, pp. 157-203.

Szállási, Á. (2008): II. Rákócri Ferenc és Ecsed. Budapest-Nagyecsed: Magyar Tudománytörténeti Intézet - Nagyecsed város Önkormányzata

\section{Internet resources}

Europien Bank for Recontruction end Development (EBRD) (2019): Transicion Report 2019-20.

https://www.ebrd.com/transition-report-2019-20

(Letöltés: 2019.12.10.)

Magyar Máltai Szeretetszolgálat (MMM) (2020): Jelenlét. https://jelenlet.maltai.hu/ (Letöltés: 2020.08.12.)

Legislation used

2003. évi CXXV. törvény az egyenlő bánásmódról és az esélyegyenlőség előmozdításáról

\section{Documentary used}

Biczó, G., Szabó, H. (2019): Kisvilágok 4, dokumentumfilm-sorozat: Nagyecsed.

\section{Statistical databases used}

Központi Statisztikai Hivatal (2019): Magyarország állandó lakosságának száma az év első napján. Budapest: KSH

Központi Statisztikai Hivatal (2002): Népszámlálás, 2001. Budapest: KSH

Román Nemzeti Statisztikai Intézet (RPL): Népszámlálás, 2011. Bukarest: 2014. 